\title{
AE 6
}

PE-066-02

REPORT OR: EXPLORATION ON QUTCLEY RIDGE, KANTISHNA DISTRICT, BY MONETA PORCUPINE MINES, LTD。, 1962

During August 14 to 37 , 1962, James no Hilliams, Director of the Livision of Mines and Minerals, and Kobert $\because$. . Saunders, State Mining ingineer, visited the Kantishma District, where Moneta Porcupine Mines, Itd., was explorhng for lead-silver deposits on Quigley Ridge。 The trip to the Kantishna District was made from Fajrbanks by auto via the Richardson, Denali, and McKinley Park highways.

The exploration conducted on Quigley Ridge by Monote

Porcupine began in 1960. The work through the 19601 season was described in a Division of Mines and Minerels report entitled PREPORT ON MLNING AND PROSPECTING ACTIVITIES IN THE KANTISHNA DISTRICT, 1961.

During 1962, geochemical surveys and trenching continued. Bosides Dr. Robert Ho Seraphim, who is in charge of the project, and Leo Mark Anthony, who is in drect charge of field work, three men were omployed on Quigley Ridge, and a fourth employee was performing assessment work on claims owned by Monota Porcupine in another part of the Kantishna District. Arlie Taylor, Kantishna District placer miner, was employed as tractor operator.

When the exploration program began on Quigley Ridge, an attempt was made to trace veins with electromagnetic equipment, but, probably because of large amounts of graphitic scinist in the area, this method was not succegsful. After electromagnetic methods failed to produce the desired results, genchemical testing for heavy-metal content of solls was tried. Geochemical anomalies were found in the soll down-slope from know veins, and, from this deginninf, the exploration 
was conducted in five stages, the last four stages progressing simultaneously。

Stage 1. Extonsions of known veins were traced by soll sampling, and the results were checked by trenching. Wher trenching proved a close association of geochemioal anomalies and veins, stage 2 was begun.

Stage 2. Systematic soil gampling on a grid network was conducted over all of Quigley Hidge. Detalled tinformation about sampling methods, chemical tests used, and amomalies detected is given in the 1961 report。

Stage 3. Trenches were dug on the anomalies deteoted by stage 2, and geochemical tests were made in the trenches to guide the digging. Trenches were extended upieslope from the upper ends of anomalies until the vein causing each anomaly was found. Through 196I, 211 of tho trenching was done by hand; hand trenching progressed slower than the geochenical surveying, and, at the end of the 1961 season, several anomalies had been found that had not been checked by trenching. In 1962, a D-6 tractor with bulzdozer blade was acquired, and use of the tractor accelerated the trenching so that by the end of the 1962 season all of the aromalies had been checked.

Stage 40 Excavations were dug by hand on the veins found in stage 3, exposing the velns sufficiently to permit channel sampling of them.

Stage 5. Channel samples were cut and prepared for assay. A small jaw-crusher powered by a gasoline engine was used for crushing the samples, and curshed samples were split by use of a Jones riffle sampler. Two splits of each sample were saved; one split was sent to the Division of Mines and Minerals Assay Offlce at College, and the other was retained by the company for possible check assay and future study. Primarily, the crushing and splitting were done to make transportation and mailing of samoles cheaper and easier.

work on the exploration program continued two to three

weaks after our visit. In liovember, 1962, Dr. Seraphin notified the

Division of Mines and Minerals that the veins that had boen uncovered were too small, and that he was not recommending any further work on them.

College, Alaska March, 1963
Roiert $\dddot{r}_{0}$ Saunders

Stats Mining Engineer. 